\title{
Unexpected hypotension in catecholamine reversal: a case report
}

\author{
Yohei Okada (D), Wataru Ishi, Hiromichi Narumiya and Ryoji Liduka
}

\begin{abstract}
Background: Catecholamine agents are commonly used to support circulation; however, they may cause unexpected hypotension in a special situation. Here we describe the first unexpected case of hypotension in response to catecholamine agents.

Case presentation: A 29-year-old Japanese man with schizophrenia was transferred to our emergency department. He was in shock and in coma. After fluid resuscitation, we induced catecholamine agents; however, his blood pressure decreased to $59 / 40 \mathrm{mmHg}$ in response to catecholamine infusion. On the other hand, after we started vasopressin, his blood pressure markedly improved, and he finally became stable. On day 2, he admitted to ingesting a large amount of risperidone, and we diagnosed risperidone overdose. We believe that this unexpected hypotension in response to catecholamine infusion was caused by an a-adrenergic blockade effect of risperidone. Animal experiments proved that the simultaneous administration of adrenaline with an a-adrenergic blockade provoked a fall in blood pressure; this phenomenon is called "adrenaline reversal." In our case, catecholamine infusion under the a-adrenergic blockade effect of risperidone might have caused a fall in blood pressure in the same mechanism; we call this phenomenon "catecholamine reversal." In such a situation, because the mechanism of vasopressin is different from that of catecholamine, we recommend vasopressin for maintaining the blood pressure.

Conclusions: We described the first clinical case of "catecholamine reversal" and highlighted that if unexpected hypotension occurs in response to catecholamine infusion, we should suspect the use of a-adrenergic antagonists. In such situations, we should consider the administration of vasopressin instead.
\end{abstract}

Keywords: Adrenaline reversal, Alpha-adrenergic blockade, Vasopressin, Noradrenaline, Side effect, Risperidone, Case report

\section{Background}

Catecholamine is commonly used to support circulation, and each catecholamine agent has different effects on different receptors. Catecholamine action on $\alpha$-adrenergic receptors promotes peripheral vasoconstriction, on $\beta_{1}$-adrenergic receptors it increases chronotropic and inotropic effects, and on $\beta_{2}$-adrenergic receptors it increases vasodilation (Fig. 1) [1]. In distributive shocks such as septic shock, we generally use catecholamine agents, including noradrenaline and dopamine, to promote vasoconstriction because they mainly affect the $\alpha$-adrenergic receptor [1]. However, in a special situation, these catecholamine agents may cause unexpected hypotension.

\footnotetext{
*Correspondence: okadayohei1127@yahoo.co.jp

Department of Emergency and Critical Care Medicine, Japanese Red Cross

Society Kyoto Daini Red Cross Hospital, 355-5 Haruobicho Kamigyoku, Kyoto 602-8026, Japan
}

(c) The Author(s). 2017 Open Access This article is distributed under the terms of the Creative Commons Attribution 4.0 International License (http://creativecommons.org/licenses/by/4.0/), which permits unrestricted use, distribution, and reproduction in any medium, provided you give appropriate credit to the original author(s) and the source, provide a link to the Creative Commons license, and indicate if changes were made. The Creative Commons Public Domain Dedication waiver (http://creativecommons.org/publicdomain/zero/1.0/) applies to the data made available in this article, unless otherwise stated.

\section{Case presentation}

A 29-year-old Japanese man with schizophrenia was transferred to our emergency department. On arrival, he presented with shock and coma. His blood pressure (BP) was $57 / 29 \mathrm{mmHg}$, heart rate (HR) was 135 beats per minute (bpm), respiratory rate was $40 /$ minute, and his body temperature was $35.6{ }^{\circ} \mathrm{C}$. His Glasgow Coma Scale score was (E1V1M1) 3. We immediately performed intubation because of his shock and coma. Fluid resuscitation of $3000 \mathrm{ml}$ crystalloid temporarily increased his BP to $73 / 28$ $\mathrm{mmHg}$, but his shock still persisted. Before a central venous line was inserted, we tentatively initiated dopamine infusion at $5 \mu \mathrm{g} / \mathrm{kg}$ per minute, which was increased to 10 $\mu \mathrm{g} / \mathrm{kg}$ per minute; however, his hypotension gradually 


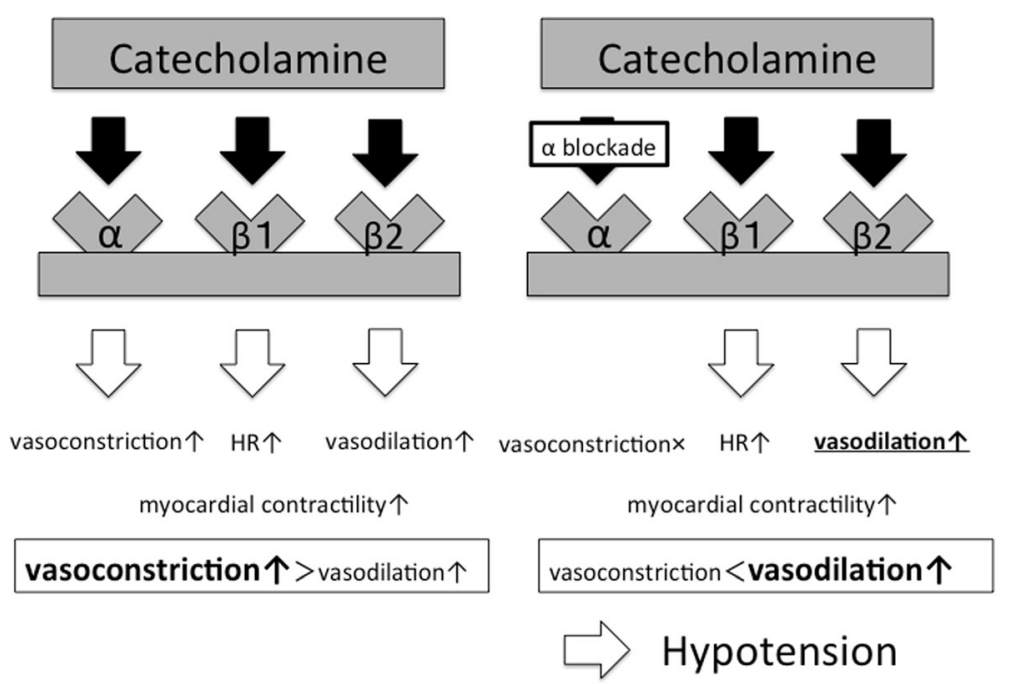

Fig. 1 Alpha-adrenergic and $\beta$-adrenergic effects of vasoactive catecholamines. Alpha-adrenergic receptors promote peripheral vasoconstriction, $\beta_{1}-$ adrenergic receptors increase chronotropic and inotropic effects, and $\beta_{2}$-adrenergic receptors increase vasodilation. If $\alpha$-adrenergic receptor antagonists are simultaneously administered with catecholamine agents, $a$-adrenergic effects are masked, and $\beta$-adrenergic effects are predominantly enhanced. Consequently, vasodilation occurs and blood pressure decreases. HR heart rate

worsened to $66 / 37 \mathrm{mmHg}$ (Fig. 2). Sixty minutes after arrival, we inserted the central venous line and initiated noradrenaline infusion at $0.1 \mu \mathrm{g} / \mathrm{kg}$ per minute, which was subsequently increased to $0.3 \mu \mathrm{g} / \mathrm{kg}$ per minute. Moreover, 90 minutes after arrival, we initiated dobutamine at $5 \mu \mathrm{g} / \mathrm{kg}$ per minute. However, his BP unexpectedly decreased to $59 / 40 \mathrm{mmHg}$. Head computed tomography, enhanced chest-abdominal computed tomography, point of care sonography, and laboratory data (Table 1) did not reveal the cause of coma and hypotension. His systemic vascular resistance index (SVRI) was very low (432 dynes/second/ $\mathrm{cm} / \mathrm{m}^{2}$; normal range, 1970 to 2400 dynes/second/ $\mathrm{cm} / \mathrm{m}^{2}$; Vigileo FloTrac ${ }^{\mathrm{Tm}}$, Edwards, USA). Thus, we suspected unknown distributive shock refractory to a large amount of catecholamine infusion. Therefore, in addition to catecholamine infusion, we initiated vasopressin at $3 \mathrm{U} /$ hour 150 minutes after arrival.

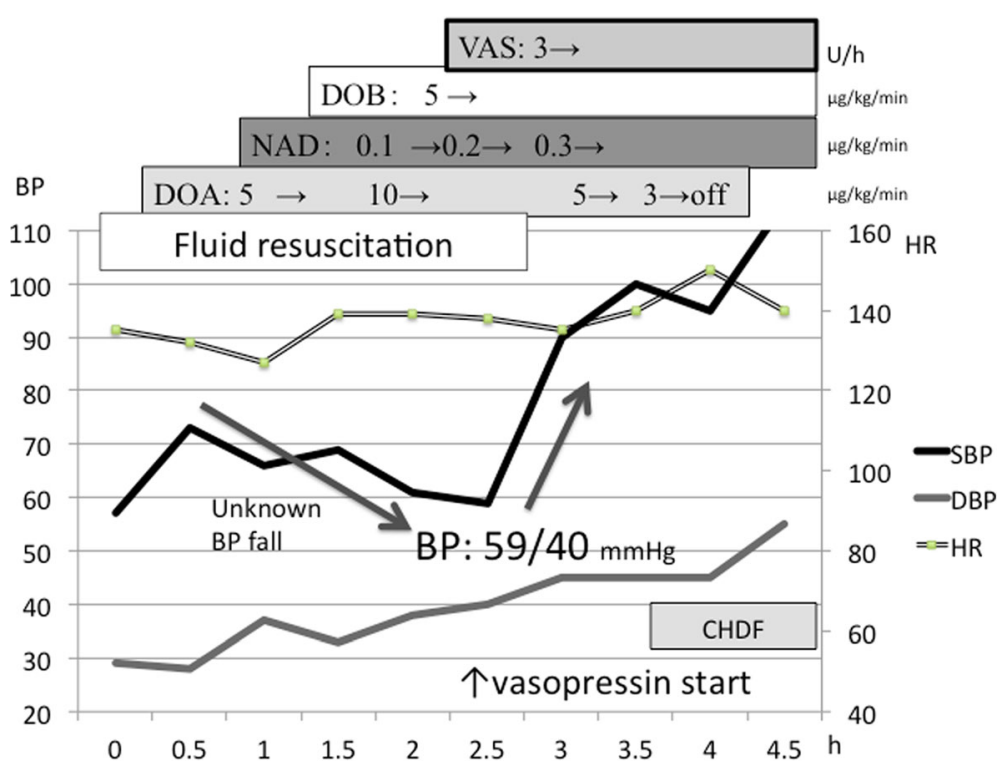

Fig. 2 Clinical course after admission. Blood pressure gradually decreased in response to an increase in catecholamine administration. After initiating vasopressin, hypotension markedly improved. BP blood pressure, CHDF continuous hemodiafiltration, DBP diastolic blood pressure, DOA dopamine, $D O B$ dobutamine, HR heart rate, NAD noradrenaline, SBP systemic blood pressure, VAS vasopressin 
Table 1 Laboratory data on admission

\begin{tabular}{|c|c|c|c|}
\hline Complete & d count & Coagulation & \\
\hline WBC & $5600 / \mu \mathrm{l}$ & PT-INR & 1.09 \\
\hline RBC & $458 \times 10^{4} / \mu l$ & APTT & 23.9 \\
\hline $\mathrm{Hb}$ & $13.1 \mathrm{~g} / \mathrm{dl}$ & Fib & $218 \mathrm{mg} / \mathrm{d}$ \\
\hline $\mathrm{Ht}$ & $40.3 \%$ & & \\
\hline Plt & $17.9 \times 10^{4} / \mu \mathrm{l}$ & Arterial blood gas & \\
\hline Chemistry & & $\mathrm{pH}$ & 7.364 \\
\hline AST & $21 \mathrm{U} / \mathrm{L}$ & $\mathrm{pCO}_{2}$ & $36.8 \mathrm{mmHg}$ \\
\hline ALT & $16 \mathrm{U} / \mathrm{L}$ & $\mathrm{pO}_{2}$ & $483 \mathrm{mmHg}$ \\
\hline CPK & $136 \mathrm{U} / \mathrm{L}$ & $\mathrm{HCO}_{3}^{-}$ & $20.4 \mathrm{mmol} / \mathrm{l}$ \\
\hline $\mathrm{Cr}$ & $1.21 \mathrm{mg} / \mathrm{d}$ & Base excess & $-3.9 \mathrm{mmol} / \mathrm{l}$ \\
\hline BUN & $15.2 \mathrm{mg} / \mathrm{d}$ & Lac & $4.9 \mathrm{mmol} / \mathrm{l}$ \\
\hline $\mathrm{Na}$ & 141 meq/l & & $\left(\mathrm{FiO}_{2} 1.0\right)$ \\
\hline K & $2.7 \mathrm{meq} / \mathrm{l}$ & & \\
\hline $\mathrm{Cl}$ & 103 meq/l & & \\
\hline CRP & $0.08 \mathrm{mg} / \mathrm{d}$ & & \\
\hline PCT & $0.03 \mathrm{ng} / \mathrm{d}$ & & \\
\hline
\end{tabular}

ALT alanine aminotransferase, APTT activated partial thromboplastin time, AST aspartate aminotransferase, $B U N$ blood urea nitrogen, $\mathrm{Cl}$ chlorine, $C P K$ creatine phosphokinase, $\mathrm{Cr}$ creatinine, $\mathrm{CRP}$ C-reactive protein, $\mathrm{Fib}$ fibrinogen, $\mathrm{FiO}_{2}$ fraction of inspired oxygen, $\mathrm{Hb}$ hemoglobin, $\mathrm{HCO}_{3}^{-}$bicarbonate, $\mathrm{Ht}$ hematocrit, $\mathrm{K}$ potassium, $\mathrm{Lac}$ lactate, $\mathrm{Na}$ sodium, $\mathrm{pCO}$, partial pressure of carbon dioxide, $\mathrm{PCT}$ procalcitonin, $\mathrm{pH}$ potential of hydrogen, Plt platelets, $\mathrm{pO}_{2}$ partial pressure of oxygen, PT-INR prothrombin time-international normalized ratio, $R B C$ red blood cells, WBC white blood cells

Subsequently, his BP markedly improved to $135 / 45$ mmHg. Three hours after arrival, we transferred him to our intensive care unit. We performed continuous hemodiafiltration because of the presence of metabolic acidosis (Table 2). We gradually decreased the amount of catecholamine infused. Approximately 12 hours after arrival, his SVRI improved to 2271 dynes/ second $/ \mathrm{cm} / \mathrm{m}^{2}$ and his hemodynamic state became stable: BP, 140/80 mmHg; HR, 95 bpm. Subsequently, we completely terminated catecholamine infusion. Moreover, we terminated continuous hemodiafiltration

Table 2 Arterial blood gas analysis in intensive care unit

\begin{tabular}{ll}
\hline $\mathrm{PaCO}_{2}$ & $34.8 \mathrm{mmHg}$ \\
$\mathrm{PaO}_{2}$ & $214 \mathrm{mmHg}$ \\
$\mathrm{HCO}_{3}^{-}$ & $14.6 \mathrm{mmol} / \mathrm{l}$ \\
Base excess & $-11.4 \mathrm{mmol} / /$ \\
$\mathrm{Na}^{+}$ & $141 \mathrm{mmol} / \mathrm{l}$ \\
$\mathrm{K}^{+}$ & $2.8 \mathrm{mmol} / /$ \\
$\mathrm{Cl}^{-}$ & $107 \mathrm{mmol} / /$ \\
$\mathrm{LaC}^{-}$ & $12.6 \mathrm{mmol} / /$ \\
$\mathrm{pH}$ & 7.246 \\
$\left(\mathrm{FiO}_{2}\right.$ 0.6) &
\end{tabular}

$\mathrm{Cl}$ chloride ion, $\mathrm{FiO}_{2}$ fraction of inspired oxygen, $\mathrm{HCO}_{3}^{-}$bicarbonate, $\mathrm{K}^{+}$ potassium ion, $\mathrm{Lac}$ lactate, $\mathrm{Na}^{+}$sodium ion, $\mathrm{PaCO}_{2}$ partial pressure of carbon dioxide in arterial blood, $\mathrm{PaO}_{2}$ partial pressure of oxygen in arterial blood, $\mathrm{pH}$ potential of hydrogen because his metabolic acidosis was improved: $\mathrm{pH}$, 7.386; partial pressure of oxygen in arterial blood $\left(\mathrm{PaO}_{2}\right), \quad 73.8 \mathrm{mmHg}$; partial pressure of carbon dioxide in arterial blood $\left(\mathrm{PaCO}_{2}\right), 39.3 \mathrm{mmHg}$; bicarbonate $\left(\mathrm{HCO}_{3}^{-}\right), \quad-1.2 \mathrm{mmol} / \mathrm{l}$; lactate $(\mathrm{Lac}), \quad 1.5$ $\mathrm{mmol} / \mathrm{l}$; and fraction of inspired oxygen $\left(\mathrm{FiO}_{2}\right), 0.3$. On day 2, we terminated vasopressin infusion. After extubation, his condition was stable: BP, 123/75 mmHg; HR, 100 bpm; and Glasgow Coma Scale score (E4V5M6), 15. He was transferred to our general ward. He admitted to ingesting approximately $150 \mathrm{mg}$ risperidone to attempt suicide. The risperidone concentration in his blood sample on admission was very high $(398 \mathrm{ng} / \mathrm{ml}$ at admission, recommended therapeutic range, 20 to $60 \mathrm{ng} / \mathrm{ml}$ [2]), which decreased to $3.60 \mathrm{ng} / \mathrm{ml}$ on day 2. Consequently, we diagnosed risperidone overdose. Subsequently, his condition was stable without any event, and he was transferred to a psychiatric ward for psychiatric care on day 5 .

\section{Discussion}

We experienced unexpected hypotension in response to catecholamine infusion, and we believe that this unexpected hypotension was caused by a pharmacological phenomenon: the catecholamine effect under the $\alpha$-adrenergic blockade effect of risperidone. In animal experiments, if adrenaline is simultaneously administered with $\alpha$-adrenergic receptor blockers such as phentolamine, the $\alpha$-adrenergic effects are masked and the $\beta_{2}$-adrenergic effects are predominantly enhanced (Fig. 1) [3]. Consequently, vasodilation occurs and the BP decreases. This unique phenomenon is called "adrenaline reversal" [3]. Adrenaline reversal has also been reported in clinical situations; paradoxical hypotension due to adrenaline infusion has been reported in a case of massive quetiapine overdose because quetiapine has an $\alpha$-adrenergic blockade effect [4]. This report suggested that adrenaline reversal occurs even in cases of massive antipsychotic overdose. This report recommended selecting noradrenaline for hypotension under an $\alpha$ adrenergic blockade effect, such as an overdose of quetiapine; however, we disagree with this. This is because other animal experiments proved that noradrenaline could also cause the same phenomenon as "noradrenaline reversal" [5], although noradrenaline has stronger $\alpha$-adrenergic effects than $\beta$-adrenergic effects. Therefore, we suggest that we should avoid noradrenaline in such a situation.

Dopamine and dobutamine also have both $\alpha$ adrenergic and $\beta$-adrenergic effects [6]; we think that there is a possibility that dopamine and dobutamine also may cause catecholamine reversal. Thus, catecholamine agents other than adrenaline can potentially provoke "catecholamine reversal" in patients who have used $\alpha$ - 
adrenergic antagonists. In our case, because risperidone has an $\alpha$-adrenergic blockade effect, a large amount of catecholamine infused under the effect of an $\alpha$ adrenergic blockade might have caused hypotension in the same mechanism.

On the other hand, vasopressin is a type of vasoactive agent that increases peripheral vasoconstriction via V1 receptors [3] and is commonly used to maintain vasoconstriction, particularly in distributive shock [1]. In our patient, severe hypotension immediately improved after administering vasopressin. This could be attributed to the fact that the mechanism action of vasopressin is different from that of catecholamines. Thus, vasopressin may be useful to support circulation in patients who have used $\alpha$-adrenergic antagonists.

This is the first clinical case to describe unexpected hypotension as "catecholamine reversal." Most antipsychotic agents have $\alpha$-adrenergic blockade; thus, this educational case highlights that we should determine which vasoactive agent should be selected for the patient who uses these medicines.

\section{Conclusions}

We described the first clinical case of "catecholamine reversal" and highlighted that if unexpected hypotension occurs in response to catecholamine infusion, we should suspect that the patient has used $\alpha$-adrenergic antagonists. In such a situation, we should consider administration of vasopressin instead.

\section{Acknowledgements}

We thank Dr Hatsuko Yano for providing clinical support.

\section{Funding}

No funding was received for this study.

\section{Availability of data and materials}

The authors agree to make the raw data and materials described in our manuscript freely available.

\section{Authors' contributions}

YO was the major contributor in writing the manuscript. RL, Wl, and HN supervised the whole work. All authors have read and approved the final manuscript.

\section{Ethics approval and consent to participate}

Not applicable.

\section{Consent for publication}

Written informed consent was obtained from the patient for publication of this case report and accompanying images. A copy of the written consent is available for review by the Editor-in-Chief of this journal.

\section{Competing interests}

The authors declare that they have no competing interests.

\section{Publisher's Note}

Springer Nature remains neutral with regard to jurisdictional claims in published maps and institutional affiliations.
Received: 2 December 2016 Accepted: 28 August 2017

Published online: 06 October 2017

\section{References}

1. Hollenberg SM. Vasoactive drugs in circulatory shock. Am J Respir Crit Care Med. 2011:183:847-55.

2. Baumann P, Hiemke C, Ulrich S, Eckermann G, Gaertner I, Gerlach M, et al. The AGNP-TDM expert group consensus guidelines: therapeutic drug monitoring in psychiatry. Pharmacopsychiatry. 2004;37:243-65.

3. Grundy HC, Grundy HF. Proceedings: The mechanism of "adrenaline reversal" in the anesthetized cat and rabbit. Br J Pharmacol. 1975;55:282-3.

4. Grace RF, Newell SD. Paradoxical and severe hypotension in response to adrenaline infusions in massive quetiapine overdose: the case for lipid rescue. Crit Care Resusc. 2009;11:162.

5. Karim SM. The mechanism of the depressor action of noradrenaline in the cat. Br J Pharmacol Chemother. 1964;23:592-9.

6. Overgaard CB, Dzavik V. Inotropes and vasopressors: review of physiology and clinical use in cardiovascular disease. Circulation. 2008;118:1047-56.
Submit your next manuscript to BioMed Central and we will help you at every step:

- We accept pre-submission inquiries

- Our selector tool helps you to find the most relevant journal

- We provide round the clock customer support

- Convenient online submission

- Thorough peer review

- Inclusion in PubMed and all major indexing services

- Maximum visibility for your research

Submit your manuscript at www.biomedcentral.com/submit
C Biomed Central 